\title{
Interaction of non-human
} primate complement and antibodies with hypermucoviscous Klebsiella pneumoniae

Esteban Soto ${ }^{1,2^{*}}$, Sylvia Marchi ${ }^{2}$, Amy Beierschmitt ${ }^{2,3}$, Michael Kearney $^{4}$, Stewart Francis ${ }^{2}$, Kimberly VanNess ${ }^{2}$, Michel Vandenplas' ${ }^{2}$ MaryAnna Thrall ${ }^{2}$ and Roberta Palmour ${ }^{3}$

\begin{abstract}
Emergent hypermucoviscosity (HMV) phenotypes of Klebsiella pneumoniae have been associated with increased invasiveness and pathogenicity in primates. In this study, we investigated the interaction of African green monkeys (AGM) (Chlorocebus aethiops sabaeus) complement and antibody with HMV and non-HMV isolates as in vitro models of primate infection. Significantly greater survival of HMV isolates was evident after incubation in normal serum or whole blood $(p<0.05)$ of AGM donors when compared to non-HMV strains. Greater survival of HMV strains $(p<0.05)$ was found after incubation in whole blood and serum from seropositive donors when compared to seronegative donor samples. Additionally, significantly greater amounts of $K$. pneumoniae were phagocytozed by AGM leukocytes when complement was active $(p<0.05)$, but no difference in uptake was observed when serum from seropositive or seronegative animals was used in challenged cells utilizing flow cytometry. Results demonstrate that interaction of cellular and humoral immune elements play a role in the in vitro killing of $K$. pneumoniae, particularly HMV isolates. Neither AGM serum, nor washed whole blood effectively killed HMV isolates; however, assays using heparinized whole blood of seronegative donors significantly reduced viability of HMV and non-HMV strains. The lack of bacterial killing observed in seropositive donors treatments could be at least partially associated with low lgG2 present in these animals. A better understanding of the pathogenesis of klebsiellosis in primates and host immune response is necessary to identify surface molecules that can induce both opsonizing and bactericidal antibody facilitating killing of Klebsiella, and the development of vaccines in human and animals.
\end{abstract}

\section{Introduction}

Klebsiella pneumoniae is a Gram-negative bacterium member of the family Enterobactericeae typically found in the environment and on mucosal surfaces. In both human and veterinary medicine this bacterium is regarded as an emergent and common nosocomial pathogen associated with a range of infections [1-6].

A novel, invasive form of $K$. pneumoniae, referred to as hypervirulent and typically presenting a hypermucoviscous (HMV) phenotype, has emerged over the last two decades [7-10]. Distinct capsular components and an

\footnotetext{
*Correspondence: sotomartinez@ucdavis.edu

1 Department of Epidemiology and Medicine, University of California,

Davis-School of Veterinary Medicine, Davis, CA, USA

Full list of author information is available at the end of the article
}

increased amount of capsular material in HMV K. pneumoniae have been described. The HMV strains have been associated with serotypes K1-K6 in humans, non-human primates, and marine mammals, and have been associated more frequently with osteomyelitis, endophthalmitis, meningitis, severe respiratory infection related with suppurative pneumonia, pleuritis, and multi systemic abscesses in the lung, liver, cervix, brain and septicemia; however lack of specific clinical presentation in klebsiellosis makes premorbid diagnosis difficult [5, 11-14]. Additionally, HMV isolates are associated with several virulence genes including $r m p A$ (regulator of mucoid phenotype) and magA (mucoviscosity-associated) [7, 15]. The magA gene encodes a $43-\mathrm{kD}$ outer membrane protein, whereas the $r m p A$ gene is a transcriptional activator of colanic acid biosynthesis [16]. 
Although $K$. pneumoniae has been recognized as an important nosocomial infection, and HMV isolates are often associated with high morbidity and mortality in a wide range of mammals, the pathogenesis of the disease and the epizootiology of the pathogen remain poorly characterized. Additionally, little work elucidating the role of the HMV phenotype in K. pneumoniae pathogenicity exists, no vaccines are available, and few studies provide direct comparison of HMV and non-HMV isolates. Recently, isolates recovered from African Green monkeys (AGM) presenting with a HMV phenotype, and belonging to serotype $\mathrm{K} 1$ and $\mathrm{K} 5$ were found to be significantly more virulent and resistant than non-HMV isolates in in vitro, serum, and oxidative-mediated killing assays [17].

To gain a better understanding about the pathogenesis of this important emergent disease in primates, and to investigate the role of innate and adaptive immune components in the protection against $K$. pneumoniae, we evaluated the role of complement and antibody in protection against $\mathrm{HMV}$ and non-HMV isolates using the AGM. An understanding of the relevant protective immune mechanisms against klebsiellosis is essential if a vaccine is to be developed in a timely manner.

\section{Materials and methods}

\section{Animal subjects and inclusion criteria}

Both the Ross University School of Veterinary Medicine and Behavioural Science Foundation Institutional Animal Care and Use Committees reviewed and approved this study. In order to assess prior exposure or current infection (clinical or sub-clinical) of $K$. pneumoniae, 25 female captive AGM, ages 5-10 years old from the Behavioural Science Foundation, St. Kitts, were screened serologically and molecularly following protocols by Cox et al. [17] (Table 2).

In order to collect blood and swabs from the AGM, animals were isolated by tunneling into a squeeze cage and anesthetized with ketamine (10 $\mathrm{mg} / \mathrm{kg}$ intramuscular) and brought to a central husbandry area for examination by a veterinarian. All of these animals were confirmed as healthy on physical examination. Depending on the experiment, whole blood (4-6 mL/animal) was collected from the femoral vein using red top, EDTA or sodium heparin vacutainer tubes (Becton Dickinson and Company, Sparks, MD, USA), and placed on ice. Six animals (three seropositive and three seronegative donors) were chosen for further investigation. They were bled three additional times giving them at least 2 weeks between sample collections. Animals recovered from anesthesia in their home cages or tunnels of their home cages. They were kept sheltered and under observation until completely recovered.
Nasal, vaginal, fecal and oral swabs were collected from the AGM and suspended in $500 \mu \mathrm{L}$ PBS and total DNA was extracted utilizing, the DNeasy Kit (nasal, vaginal and oral) or the QIAamp DNA Stool Mini Kit (fecal) (Qiagen, Valencia, CA, USA). Extracted DNA served as a template in a real-time PCR assay for the detection of the K. pneumoniae khe, $\operatorname{rpm} A$, or magA genes (Table 2) following published protocols [18]. Blood collected from donor animals was subjected to complete blood counts and biochemical analysis of plasma using Abaxis HM5c Hematology Analyzer and Abaxis VetScan VS2 (Abaxis North America, Union City, CA, USA). Additionally, protein electrophoresis analysis of serum was performed at Kansas State University Veterinary Diagnostic Laboratory using the TITAN GEL Serum Protein System (Helena Laboratories, Beaumont, TX, USA).

\section{Bacterial strains and culture conditions}

Klebsiella pneumoniae strains cultured from AGM with single or multifocal abscesses were isolated at the Ross University School of Veterinary Medicine Diagnostic Laboratory from 2010 to 2012. Identification and characterization of the isolates was made according to standard clinical microbiologic and molecular methods (Table 1) $[6,17,18]$. For general use, K. pneumoniae was grown on $5 \%$ sheep blood agar plates, brain-heart infusion broth (BHI) or Luria-Bertani (LB) broth (Sigma-Aldrich, St. Louis, MO, USA) at $37^{\circ} \mathrm{C}$. The mucoviscosity levels were determined by string test and centrifugation (Table 1) $[19,20]$. Briefly, K. pneumoniae isolates were cultivated at $37^{\circ} \mathrm{C}$ overnight. The following morning $1.2 \mathrm{~mL}$ of optical density $(\mathrm{OD})_{600}$ normalized bacteria grown in LB broth was centrifuged in microcentrifuge tubes at $2000 \mathrm{~g}$ for $5 \mathrm{~min}$. The absorbance of the supernatant was measured at $\mathrm{OD}_{600}$. A representative $\mathrm{K} 1, \mathrm{~K} 5$ and non-HMV isolate previously characterized were used for in vitro challenges [17].

Serologic assays for anti-K. pneumoniae immunoglobulins Indirect ELISA was used to determine AGM IgG and IgM antibody concentrations against HMV and nonHMV-K. pneumoniae in serum from seropositive and seronegative donors. Protocols described by Cox et al. [17] were followed with modifications. Briefly, BD Falcon 96-well black/clear flat-bottom microtitre plates (Becton Dickinson and Company, Sparks, MD, USA) were coated with $5 \times 10^{6}$ colony forming units (CFU) per well live $K$. pneumoniae in carbonate coating buffer, $\mathrm{pH}$ 9.6, at $100 \mu \mathrm{L}$ per well, and incubated overnight at $4{ }^{\circ} \mathrm{C}$. Plates were washed three times in PBS containing $0.05 \%$ Tween-20 (PBST), and blocked for $1 \mathrm{~h}$ at room temperature (RT) with ELISA Blocking Buffer (Sigma-Aldrich, St. Louis, MO, USA). Serum samples were diluted 1:50 
Table 1 Klebsiella pneumoniae isolates used in this study

\begin{tabular}{|c|c|c|c|c|c|c|c|}
\hline $\begin{array}{l}\text { Isolate } \\
\text { designation }\end{array}$ & $\begin{array}{l}\text { Species } \\
\text { identification }\end{array}$ & $\begin{array}{l}\text { Host isolated } \\
\text { from }\end{array}$ & $\begin{array}{l}\text { HMV phenotype } \\
\text { as determined } \\
\text { by string test }^{\mathrm{a}}\end{array}$ & $\begin{array}{l}\text { Detection } \\
\text { of } k h e^{b}\end{array}$ & $\begin{array}{l}\text { Detection } \\
\text { of } r m p A^{\mathbf{b}}\end{array}$ & $\begin{array}{l}\text { Detection } \\
\text { of } m a g A^{b}\end{array}$ & Serotype $^{c}$ \\
\hline $\mathrm{K} 1$ & $\begin{array}{l}\text { Klebsiella } \\
\text { pneumoniae }\end{array}$ & AGM & Positive $(+++)$ & Positive & Positive & Positive & $\mathrm{K} 1$ \\
\hline $\mathrm{K} 5$ & $\begin{array}{l}\text { Klebsiella } \\
\text { pneumoniae }\end{array}$ & AGM & Positive $(++)$ & Positive & Positive & Negative & $\mathrm{K} 5$ \\
\hline NHM & $\begin{array}{l}\text { Klebsiella } \\
\text { pneumoniae }\end{array}$ & AGM & Negative & Positive & Negative & Negative & ND \\
\hline
\end{tabular}

AGM: African green monkey, ND: not determined.

a Done as described in $[19,20]$.

b Done as described in [18].

c Done as described in [15].

in PBST. Negative control wells were incubated with PBST alone. Plates were incubated overnight at $4{ }^{\circ} \mathrm{C}$ and washed $5 \times$ with PBST. Rabbit polyclonal to Human IgGFITC, or Rabbit Anti-Human IgM H\&L-FITC secondary antibodies (Abcam, Cambridge, MA, USA) were diluted in PBST following manufacturer recommendations, and $100 \mu \mathrm{L}$ were added to each well. After incubation at room temperature for $2 \mathrm{~h}$, the plate was washed $5 \times$ with PBST before adding $100 \mu \mathrm{L}$ of PBST. Fluorescence at excitation of $493 \mathrm{~nm}$ and emission of $528 \mathrm{~nm}$ was recorded using the Infinite M200 96-well-plate reader (Tecan Group Ltd., Mannedorf, Switzerland).

Quantification of IgG sub-types in donor samples was performed using PeliClass human IgG subclass kit following manufacturer's instructions (Sanquin Reagents, Amsterdam, The Netherlands).

\section{Serologic assays for K. pneumoniae complement deposition}

Indirect ELISA was used to compare complement C3/ C3b and C5-9 (membrane attack complex) deposition on $K$. pneumoniae using serum from seropositive and seronegative donors. Protocols described by Cox et al. [17] were followed with modifications. Seeding of antigen was done as previously described. After overnight incubation at $4{ }^{\circ} \mathrm{C}$, wells were washed $5 \times$ with PBST. Mouse monoclonal to $\mathrm{C} 3 / \mathrm{C} 3 \mathrm{~b}$, or Mouse monoclonal to $\mathrm{C} 5 \mathrm{~b}-9$ secondary antibody (Abcam, Cambridge, MA, USA) were diluted in PBST following manufacturer recommendations, and $100 \mu \mathrm{L}$ were added to each well. Plates were incubated at RT for $2 \mathrm{~h}$, followed by $5 \times$ washes with PBST before adding Rat monoclonal to IgG2a HRP (Abcam) as tertiary antibody. After incubation at $25^{\circ} \mathrm{C}$ for $1 \mathrm{~h}$, the plate was washed $5 \times$ with PBST before adding $100 \mu \mathrm{L}$ of ABTS Peroxidase Substrate (KPL, Gaithersburg, MD, USA) to each well. The ELISA reaction was stopped after 30 min with $100 \mu \mathrm{L} 1 \%$ sodium dodecyl sulfate, and the optical density (OD) of the reactions was read at $405 \mathrm{~nm}$ with a SpectraMax M2/M2e Microplate Reader (Molecular Devices, Sunnyvale, CA, USA).

\section{Klebsiella serum and whole blood killing assays}

Whole blood and serum bactericidal assays developed by MacLennan et al. [21] were modified to investigate in vitro killing of serum sensitive $E$. coli, HMV and nonHMV K. pneumoniae isolates. Blood or serum from three seropositive and three seronegative donors was used (Table 2). Killing of different bacterial isolates was assessed using (a) heparinized blood (4 IU/mL sodium heparin) within $2 \mathrm{~h}$ of venesection; (b) serum separated within $2 \mathrm{~h}$ and stored at $-80{ }^{\circ} \mathrm{C}$; (c) heat inactivated serum (inactivated by heating serum to $56{ }^{\circ} \mathrm{C}$ for $30 \mathrm{~min}$ ); or (d) blood-cell-suspensions, prepared by washing blood twice with Roswell Park Memorial Institute (RPMI)-1640 medium (Gibco by Life Technologies, Grand Island, NY, USA) to remove antibody and complement before resuspending in RPMI to the original blood volume (whole blood-RPMI). Viable bacteria $\left(2 \times 10^{5}\right.$ in $\left.20 \mu \mathrm{L}\right)$, were added to $180 \mu \mathrm{L}$ of $100 \%$ whole blood, undiluted serum (normal and heat-inactivated), or blood-cell-suspensions to give a final bacterial concentration of $1 \times 10^{6} / \mathrm{mL}$ regardless of white cell count. These mixtures were then incubated at $37^{\circ} \mathrm{C}$ on a rocker plate at $20 \mathrm{rpm}$. Numbers of viable bacteria were determined after $60 \mathrm{~min}$ by serial dilution of $20 \mu \mathrm{L}$ of the mixture plated in triplicate on blood agar plates.

\section{Phagocytosis by peripheral blood mononuclear and polymorphonuclear leukocytes assays}

Within $1 \mathrm{~h}$ of collection, peripheral blood mononuclear cells (PBMC) and polymorphonuclear leukocytes (PMNL) were purified from blood collected in EDTA using Histopaque 1077 (Sigma-Aldrich, St. Louis, MO, USA) following manufacturer's instructions and published protocols 
Table 2 Inclusion criteria for African Green monkey donors in this study

\begin{tabular}{|c|c|c|c|c|c|c|c|c|c|c|}
\hline \multirow[t]{2}{*}{ Donor } & \multirow[t]{2}{*}{ Age (years) } & \multirow{2}{*}{$\begin{array}{l}\text { Sex } \\
\text { Female }\end{array}$} & \multicolumn{3}{|c|}{ Anti-Klebsiella pneumoniae IgG titers ${ }^{a}$} & \multicolumn{4}{|c|}{$\begin{array}{l}\text { Isolation of } K . \text { pneumoniae or detection of } k h e \text {, } \\
r m p A \text { or } m a g A \text { related genes }{ }^{b}\end{array}$} & \multirow[t]{2}{*}{$\begin{array}{l}\text { Donor des- } \\
\text { ignation }\end{array}$} \\
\hline & & & K1 & K5 & Non-HMV & Fecal & Oral & Vaginal & Nasal & \\
\hline 1 & 11 & Female & 8192 & 8192 & 8192 & - & - & - & - & Seropositive \\
\hline 2 & 5 & Female & 8192 & 8192 & 2048 & - & - & - & - & Seropositive \\
\hline 3 & 5 & Female & 16384 & 8192 & 8192 & - & - & - & - & Seropositive \\
\hline 4 & 5 & Female & 1024 & 1024 & 1024 & - & - & - & - & Seronegative \\
\hline 5 & 5 & Female & 512 & 256 & 512 & - & - & - & - & Seronegative \\
\hline 6 & 6 & Female & 1024 & 1024 & 1024 & - & - & - & - & Seronegative \\
\hline
\end{tabular}

a According to [17].

b According to [18].

[17]. Erythrocytes were removed by hypotonic lysis in water for $30 \mathrm{~s}$ and isotonic conditions restored immediately by adding an equal volume of $2 \times$ PBS. Thereafter the PMNL were washed twice in PBS and collected by low speed centrifugation. Viability of PMNL and PBMC was verified using trypan blue exclusion assays. PMNL and PBMC were plated at a concentration $1 \times 10^{6}$ per well in 24-well tissue culture plates (Becton Dickinson and Company, Sparks, MD, USA). After a $2 \mathrm{~h}$ incubation at $37^{\circ} \mathrm{C}$, cells were challenged with a suspension of bacteria in cell culture medium containing 10\% serum (normal or heat inactivated from seropositive or seronegative donors) to obtain an multiplicity of infection (MOI) of 1:20 (leukocyte to bacteria). One hour post-incubation, wells were washed with PBS and incubated for $1 \mathrm{~h}$ with fresh medium containing gentamicin $(100 \mu \mathrm{g} / \mathrm{mL})$ (SigmaAldrich, St. Louis, MO, USA) to kill extracellular bacteria, followed by three washes with $\mathrm{PBS}$, and later lysis by incubation in PBS supplemented with $0.5 \%$ Triton X-100 (Sigma-Aldrich). Internalized bacteria were quantified by plating appropriate dilutions on agar plates.

\section{Oxidative burst assay}

The Bursttest assay (Becton Dickinson) and protocols by Gondwe et al. [22] and Lin et al. [23] were used to measure oxidative burst activity in AGM PMNL and PBMC by flow cytometry by determining oxidation of dihydrorhodamine to rhodamine. Opsonization was by incubating $10^{9} / \mathrm{mL}$ of heat-killed K. pneumoniae in serum obtained from seropositive and seronegative donors for $1 \mathrm{~h}$ at room temperature at a ratio of 1:10. RPMI washed cells were stimulated with opsonized heat-killed $K$. pneumoniae at $2 \times 10^{8} / \mathrm{mL}$ for 10 and $60 \mathrm{~min}$ at $37^{\circ} \mathrm{C}$ according to the manufacturer's instructions before incubating with dihydrorhodamine. Following red cell lysis and fixation, leukocytes were analyzed on a FACSCalibur flow cytometer (Becton Dickinson). PMNL and PBMC were gated according to light scatter characteristics. Rhodamine fluoresces in the FL1 channel and oxidative burst activity was measured according to the manufacturer's instructions as geometric mean fluorescence intensity from the FL1 histogram (arbitrary units). Controls consisted of PMA, fMLP, pre-opsonized E. coli and TLR-2 $\left(\mathrm{PAM}_{3} \mathrm{CSK}_{4}\right)$ stimulation.

\section{Statistical analysis}

The SAS $^{\circledR}$ (version 9.4, SAS Institute, Cary, NC, USA) GLM procedure was used to conduct an analysis of variance in a factorial arrangement of treatments. When overall significance was found post hoc comparisons were conducted with pairwise $t$ tests of least-squares means. All tests were considered significant at $p \leq 0.05$.

\section{Serum and whole blood killing assays}

Effects in the model included isolate (K1, K5, NHM, E. coli), treatment (whole blood cells, whole blood-RPMI, normal serum, heat-inactivated serum) and titer of donor (seropositive or seronegative) and the two-way and threeway interactions.

\section{AGM PMNL and PBMC uptake of Klebsiella pneumoniae}

Effects in the model included isolate ( $\mathrm{K} 1, \mathrm{~K} 5, \mathrm{NHM}$ ), treatment (normal serum, heat-inactivated serum) and titer of donor (seropositive or seronegative) and the twoway and three-way interactions.

Immonuglobulin IgG and IgM and complelement proteins C3/ C $3 b$ and C5-9 binding to Klebsiella pneumoniae

Effects in the model included isolate (K1, K5, NHM), and titer of donor (seropositive or seronegative) and the twoway interaction.

\section{Immonuglobulin IgG subtype quantification in serum from seropositive and seronegative AGM donors}

Two-sample $t$ tests assuming equal variance were used to statistically compare IgG1, IgG2, IgG3 and IgG4 levels in 
seropositive and seronegative donors. $P \leq 0.05$ was considered significant.

\section{Results}

\section{Serologic and molecular diagnosis of klebsiellosis} in African green monkey donors

Real-time amplification of oral, nasal, vaginal and fecal swab material did not detect the khe, $m a g A$, or $r m p A$ gene in any of the sampled monkeys. Three animals were classified as seropositive donors based on IgG titers $>8192$ against $K$. pneumoniae isolates $\mathrm{K} 1$ and $\mathrm{K} 5$ (Table 2; Figure 1). On the other hand, three seronegative donors were included presenting IgG titres of $\leq 1024$ (Table 2; Figure 1). Similar amounts of anti-K. pneumoniae $\mathrm{K} 1$ and $\mathrm{K} 5$ IgM were detected in seropositive and seronegative donors (Figure 1). Significantly greater amount of anti-K. pneumoniae IgG and IgM binding to non-HMV isolates was detected when compared to those binding to $\mathrm{K} 1$ or $\mathrm{K} 5$ isolates. Complete blood counts, serum clinical chemistries, and protein electrophoresis of serum resulted in similar values between seropositive and seronegative donors (data not shown).

\section{IgG quantification in donor monkeys}

Concentrations of IgG1, IgG3 and IgG4 were similar in seropositive and seronegative donors $(p<0.05)$; however, levels of IgG2 antibodies were significantly lower in the seropositive donors $(p=0.004)$ (Figure 2).

\section{Complement binding to opsonized $K$. pneumoniae}

Greater binding of $\mathrm{C} 3 / \mathrm{C} 3 \mathrm{~b}$ to $\mathrm{K} 1$ and $\mathrm{K} 5 \mathrm{~K}$. pneumoniae was found in serum from seropositive donors than in serum from seronegative donors $(p<0.05)$ (Figure 3$)$. There was similar binding of C3/C3b to NHM, K1 and $\mathrm{K} 5$ isolates $(p>0.05)$. Additionally, similar binding of C5-9 was detected when using serum of seropositive and seronegative donors, and in NHM, K1 and $\mathrm{K} 5$ isolates $(p>0.05)$ (Figure 3).

\section{Blood and serum killing of $K$. pneumoniae isolates}

Similar survival was detected in serum-sensitive E. coli, NHM, K1 and K5 K. pneumoniae isolates when incubated in heat-inactivated serum from seropositive and seronegative donors $(p>0.05)$ (Figure $4 \mathrm{~A})$. There was $100 \%$ survival in all treatments. K1 and K5 K. pneumoniae presented significantly greater survival than nonHMV isolates when challenged with normal serum collected from seropositive and seronegative donors $(p<0.05)$ (Figure 4B). Although not significant $(p>0.05)$, there was greater survival of $\mathrm{K} 1$ and $\mathrm{K} 5 \mathrm{~K}$. pneumoniae isolates in normal serum from seropositive, as compared to seronegative donors. No difference in survival

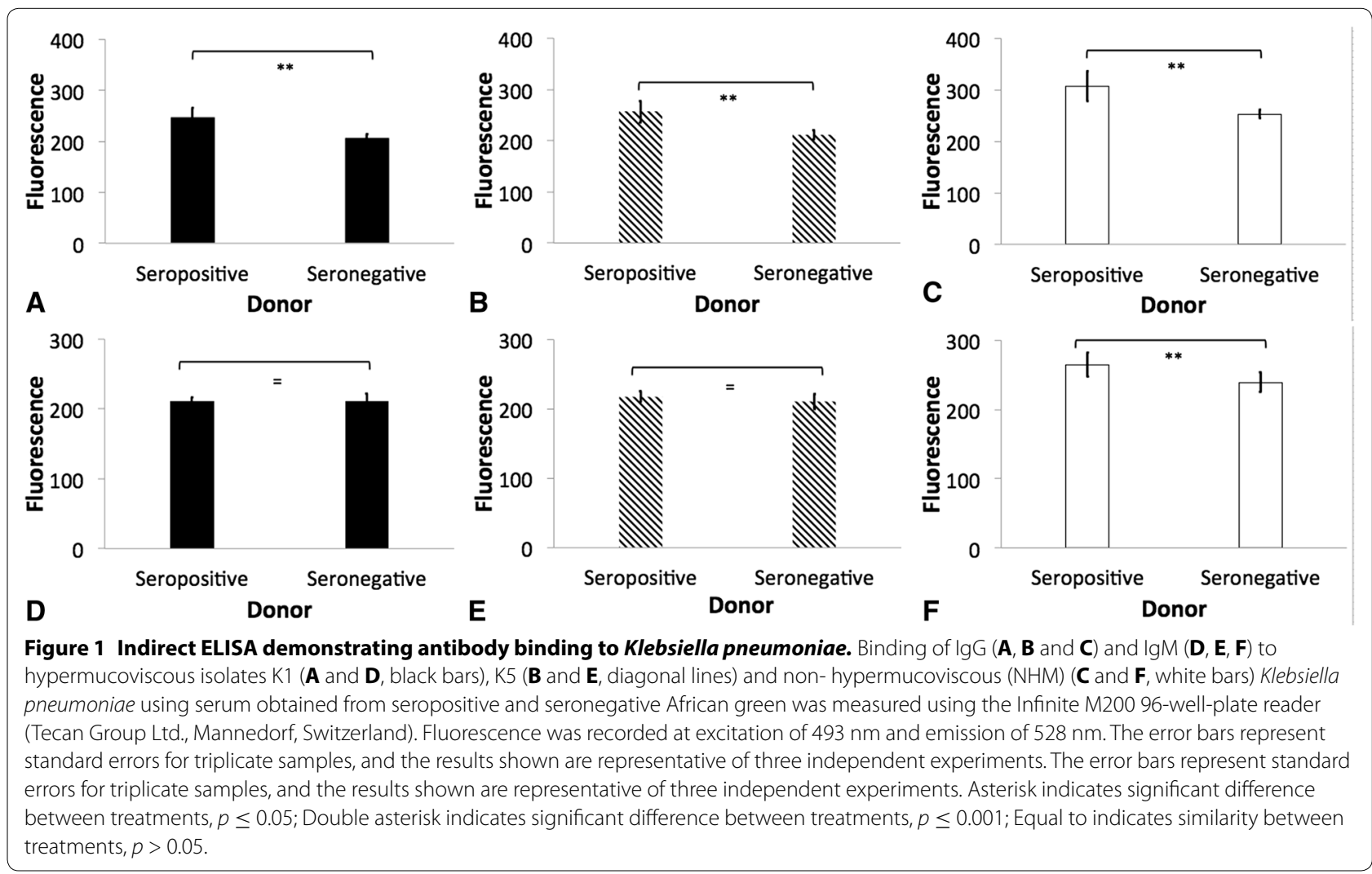



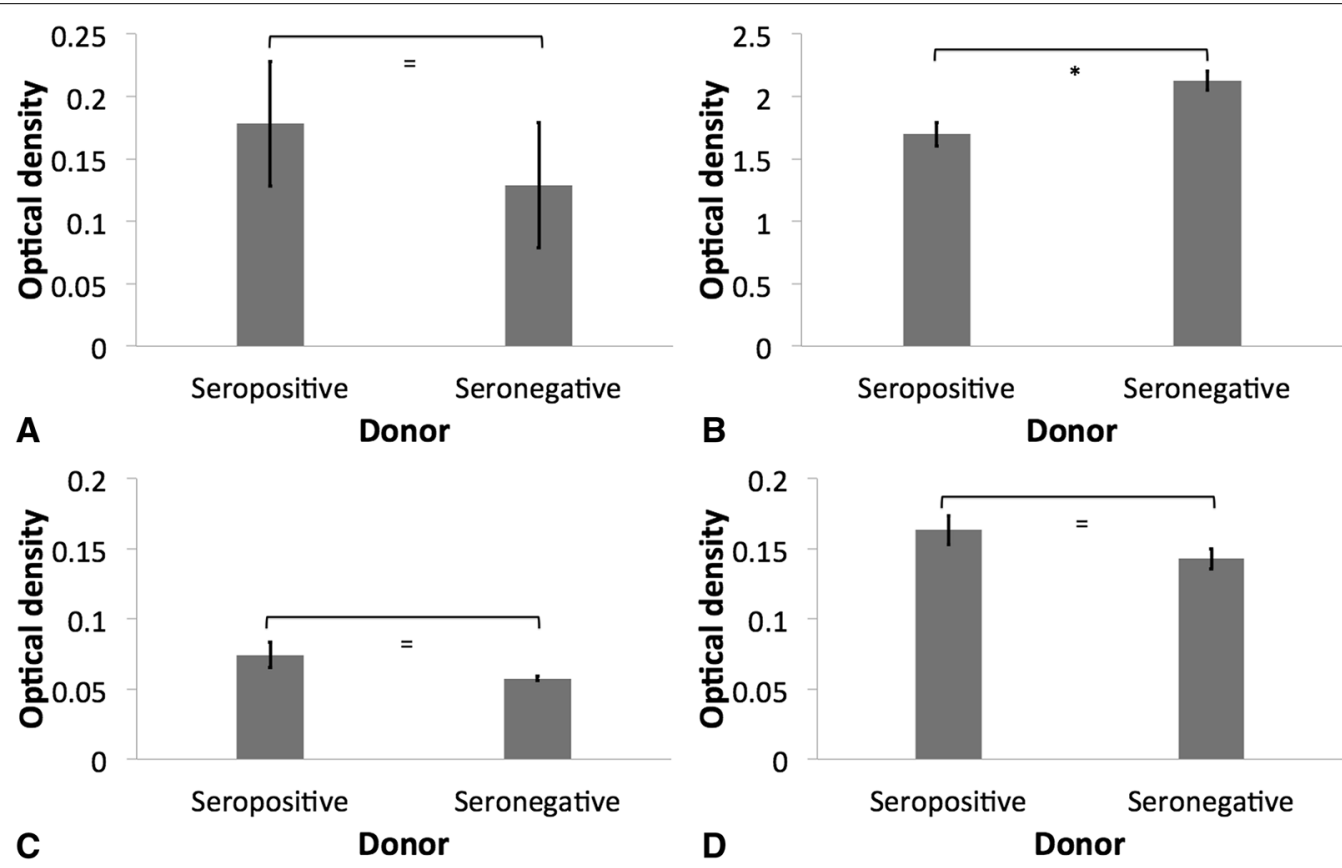

Figure 2 Quantification of IgG sub-types in serum obtained from seropositive and seronegative African green monkey donors. $\operatorname{lgG1}(\mathbf{A}), \operatorname{lgG} 2(\mathbf{B}), \operatorname{lgG} 3(\mathbf{C})$ and $\lg G 4$ (D) in donor serum were quantified using PeliClass human lgG subclass kit following manufacturer's instructions (Sanquin Reagents, Amsterdam, The Netherlands). Optical density of the reactions was read with a SpectraMax M2/M2e Microplate Reader (Molecular Devices, Sunnyvale, CA, USA). The error bars represent standard errors for triplicate samples, and the results shown are representative of three independent experiments. The error bars represent standard errors for triplicate samples, and the results shown are representative of three independent experiments. Asterisk indicates significant difference between treatments, $p \leq 0.05$; Double asterisk indicates significant difference between treatments, $p \leq 0.001$; Equal to indicates similarity between treatments, $p>0.05$.

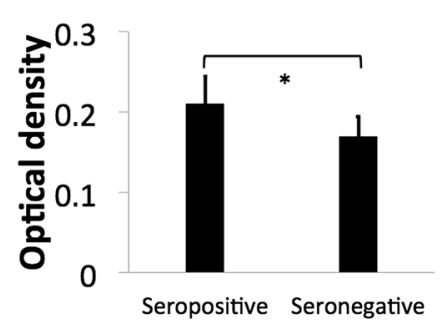

A

Donor

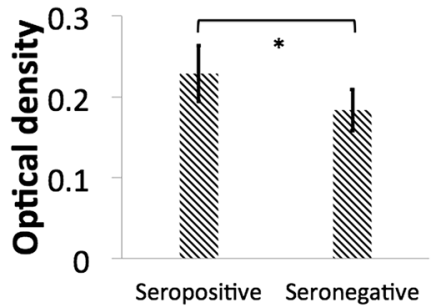

B

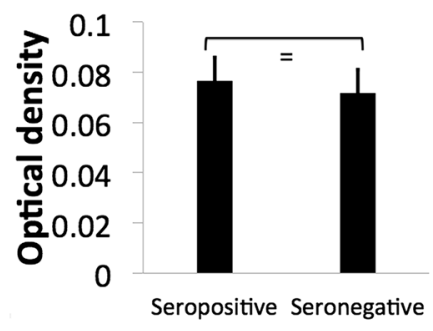

D

Donor

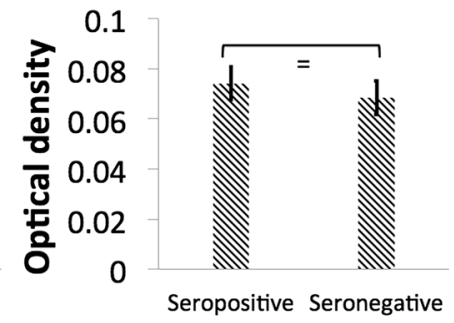

Donor

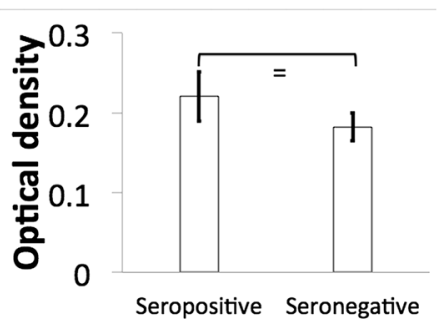

C

Donor

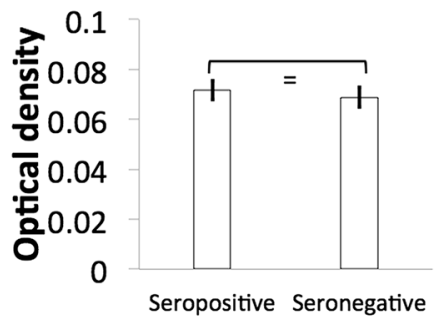

Donor

Figure 3 Indirect ELISA demonstrating complement binding to Klebsiella pneumoniae. Binding of C $3 / C 3 b(\mathbf{A}, \mathbf{B}$ and $\mathbf{C})$ and $C 5-9$ (D, E and F) to hypermucoviscous isolates K1 (A and $\mathbf{D}$, black bars), K5 (B and E, diagonal lines), and non- hypermucoviscous (NHM) (C and $\mathbf{F}$, white bars) Klebsiella pneumoniae using serum obtained from seropositive and seronegative African green monkey was estimated by optical density measured with a SpectraMax M2/M2e Microplate Reader (Molecular Devices, Sunnyvale, CA, USA). The error bars represent standard errors for triplicate samples, and the results shown are representative of three independent experiments. Asterisk indicates significant difference between treatments, $p \leq 0.05$; Double asterisk indicates significant difference between treatments, $p \leq 0.001$; Equal to indicates similarity between treatments, $p>0.05$. 


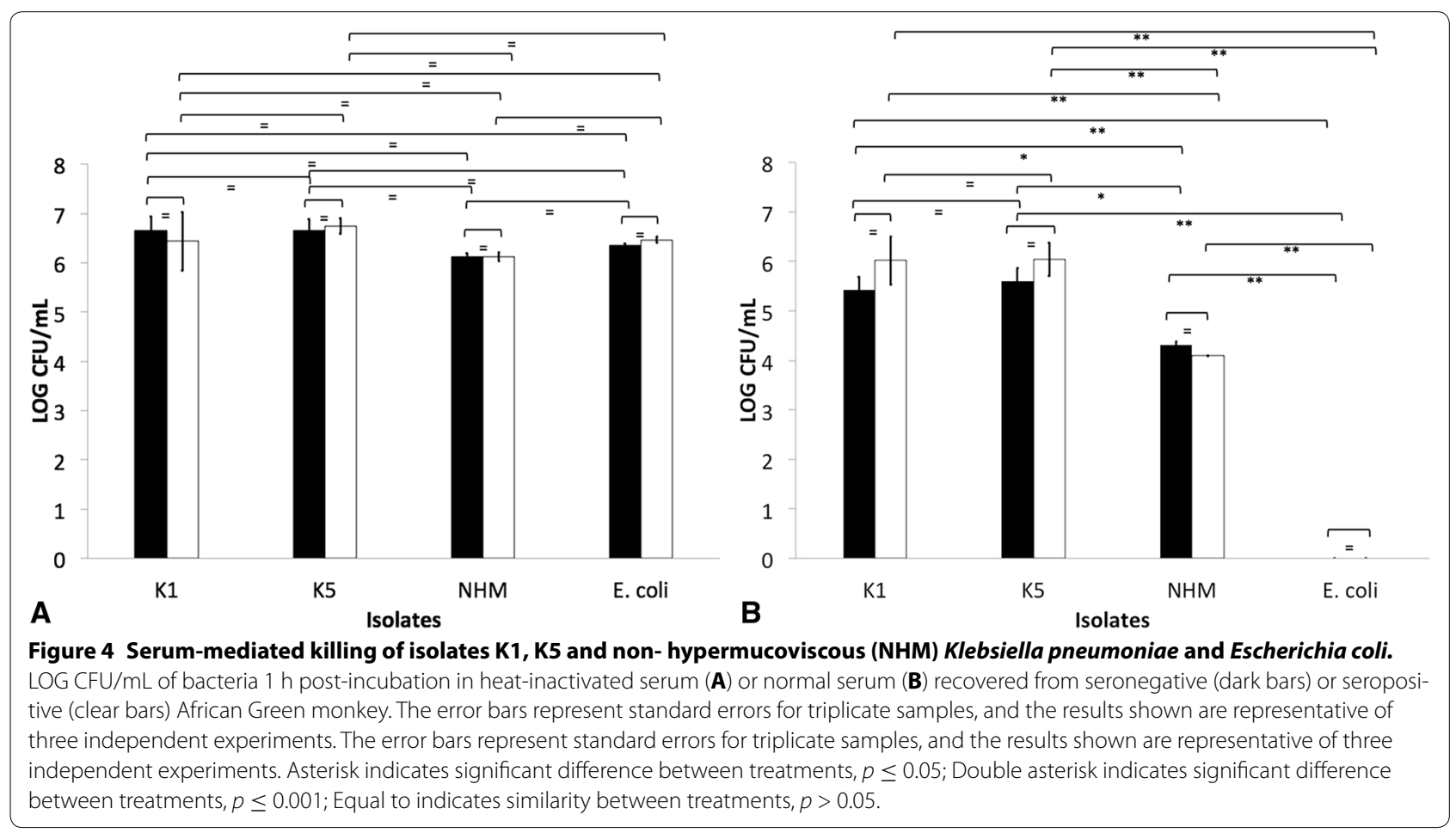

was detected between $\mathrm{K} 1$ and $\mathrm{K} 5 \mathrm{~K}$. pneumoniae isolates $(p>0.05)$. Additionally, E. coli was significantly more susceptible than HMV and non-HMV $K$. pneumoniae isolates $(p<0.05)$ (Figure 4B).

When incubated in whole blood-RPMI collected from seropositive or seronegative donors, similar survival was detected in NHM, K1 and K5 K. pneumoniae $(p>0.05)$; however, all serum-sensitive $E$. coli were killed (Figure 5A). Significantly greater survival of K1, K5 and NHM K. pneumoniae isolates was detected after incubation in heparinized blood from seropositive donors as compared to that from seronegative donors $(p<0.05)$ (Figure 5B). Significantly greater survival was detected in HMV isolates (K1 and K5) than in non-HMV K. pneumoniae isolates $(p<0.05)$. All E. coli was killed (Figure 5B).

\section{Uptake of opsonized K. pneumoniae by AGM leukocytes}

AGM PMBC and PMNL phagocytized significantly greater amounts of $\mathrm{K} 1, \mathrm{~K} 5$ and NHM K. pneumoniae when complement was active $(p<0.05)$ (Figures $6,7,8)$. Similar numbers of K5 and NHM $K$. pneumoniae were taken up by AGM PMBC and PMNL when opsonized with normal serum from seropositive and seronegative donors (Figures 6, 7, 8); however, significantly greater amounts of $\mathrm{K} 1$ were taken up by AGM PMBC when opsonized with normal serum from seronegative donors. Significantly lower amounts of K1 were taken up by PMNL when compared to other isolates, even in the presence of normal serum $(p<0.05)$ (Figures $6,7,8)$.

No oxidative burst activity in AGM PMNL and PBMC was detected after challenge with $K$. pneumoniae previously opsonized with normal serum or heat inactivated-serum from seropositive and seronegative donors. Stimulation of oxidative burst activity in AGM PMNL and PBMC with PMA, fMLP, pre-opsonized E. coli and TLR-2 $\left(\mathrm{PAM}_{3} \mathrm{CSK}_{4}\right)$ resulted in positive detection when using the modified protocols of Gondwe et al. [22], using the PHAGOBURST kit (data not shown).

\section{Discussion}

The components of the innate immune system, including humoral elements like complement, and cellular elements like PMNL and PBMC are critical to protect the host upon bacterial infection. Additionally, there is evidence of a role for both bactericidal and opsonizing antibody in immunity to members of the family Enterobactericeae $[21,22,24]$. On the other hand, bacterial pathogens acquire and employ different virulence factors upon contact with innate and adaptive immune system of the host to ensure colonization and dissemination within the host. Some of the best characterized virulence determinants of $K$. pneumoniae are the capsule, lipopolysaccharides, siderophores, and types 1 and 3 fimbriae [25]. As with other Gram-negative bacteria, the capsule 


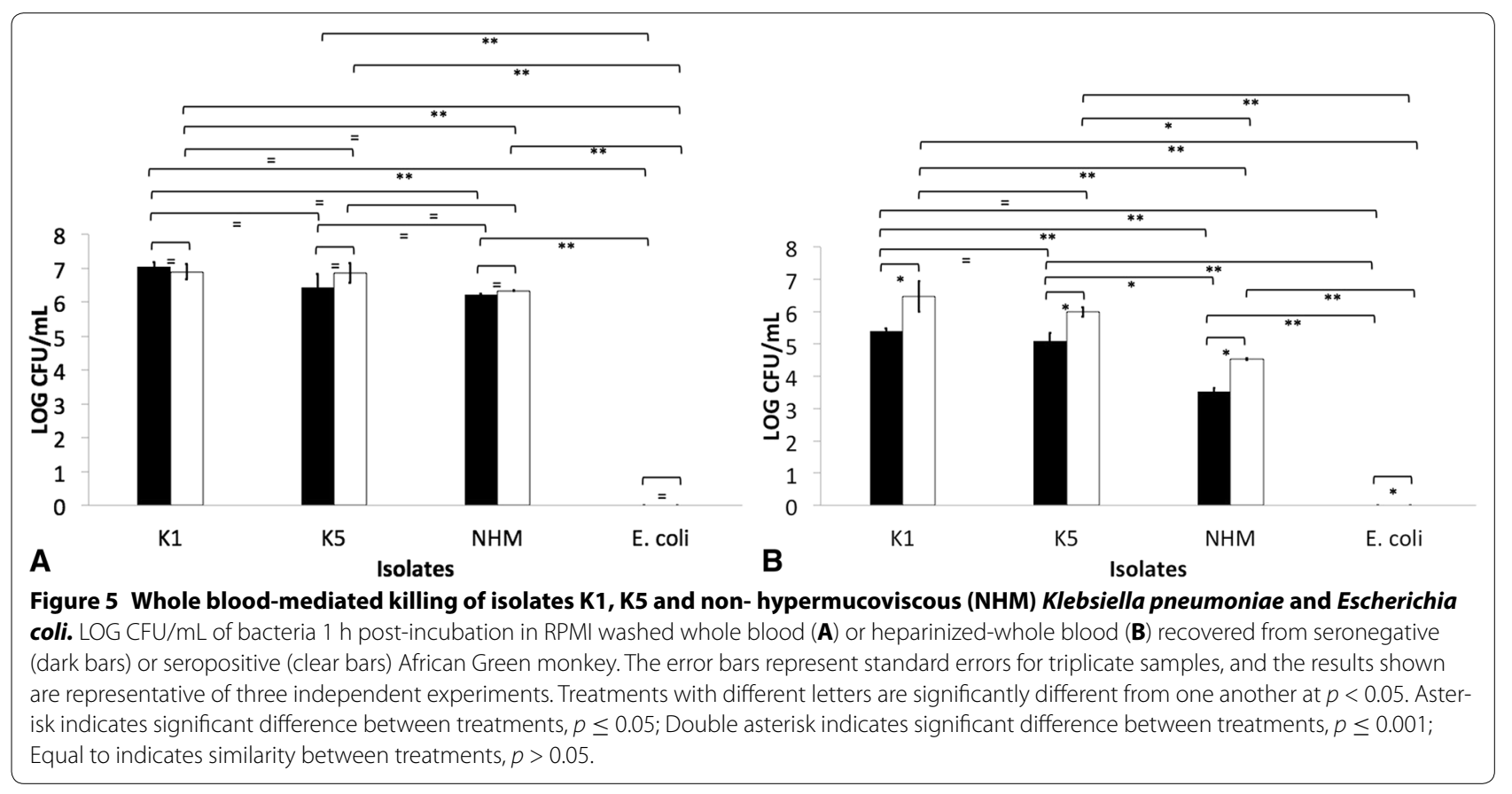

is associated with attachment to host receptors, protection from phagocytosis, and with barrier function against innate host defense components such as complement, lysozyme, and oxidative mediated killing [26]. Distinct capsular components and an increased amount of capsular material in HMV K. pneumoniae have been described in hypervirulent $K$. pneumoniae human isolates [10]. However, little work elucidating the role of the HMV phenotype in K. pneumoniae pathogenicity exists, and no direct comparison of HMV and non-HMV isolates using components of the innate and adaptive immune system of naturally susceptible hosts has been performed. Here we examined the potential role of antibody and complement in the control of $K$. pneumoniae using in vitro assays. African green monkeys are not only extremely important animals in biomedical research, but also are naturally susceptible to K. pneumoniae infections. Due to their close phylogenetic relationship to humans, they are recognized as an intermediate animal model between humans and rodents, and are an indispensable model for human diseases $[27,28]$.

The role of complement and antibodies and its interaction in conferring protection against klebsiellosis appears complex, particularly for HMV K. pneumoniae. In this study, HMV isolates ( $\mathrm{K} 1$ and $\mathrm{K} 5$ ) were found to be resistant to complement-mediated killing as indicated by AGM serum and whole blood killing assays (Figures 4 and 5). Non-HMV isolates were at least partially susceptible to its effect as the removal of killing was observed in serum with heat inactivation of complement (Figures 4 and 5).
Isolates $\mathrm{K} 1$ and $\mathrm{K} 5$ produced a significantly more mucoid capsule, than isolates designated non-HMV strains, and $\mathrm{K} 1$ was found more mucoid than K5 serotypes $(p<0.05)$ (Figure 9; Table 1). The biological significance of the greater mucoviscosity found in HMV K1 isolates when compared to HMV K5 isolates is unknown. The amount of capsular polysaccharides produced by $K$. pneumoniae is suspected to be significantly more important for resistance against complement than its chemical composition [29]; and together with lipopolysaccharide (LPS), these two virulence factors appear as major mechanisms of resistance to the bactericidal activity of complement [29-31]. Our results indicate similar resistance to complement by $\mathrm{K} 1$ and $\mathrm{K} 5 \mathrm{HMV}$ isolates (Figures 4 and 5); however, K5 were phagocytized by PBMC and PMNL) in greater amounts than $\mathrm{K} 1$ isolates in the presence of normal serum $(p=0.0006$ and $p=0.0020$, respectively) (Figures 6 and 7). Similar findings were reported by Cox et al. [17] were $k h e+, \operatorname{rmp} A+, \operatorname{magA}-$ isolates associated with the AGM PBMC to a greater extent than khe+, $\operatorname{rmp} A+, \operatorname{mag} A+)$, isolates $(p<0.05)$.

The complement system is an important component of innate immunity that consist of a cascade of soluble proteins and membrane-expressed receptors and regulators, which operates in plasma, tissues, cell surfaces and even within the cell. Complement (C3) activation can proceed via three enzymatic cascades, the classical, the alternative, and the mannose-binding lectin (MBL) pathways. The classical complement pathway is initiated by the binding of $\mathrm{C} 1 \mathrm{q}$ to the Fc portion of antibody-antigen 

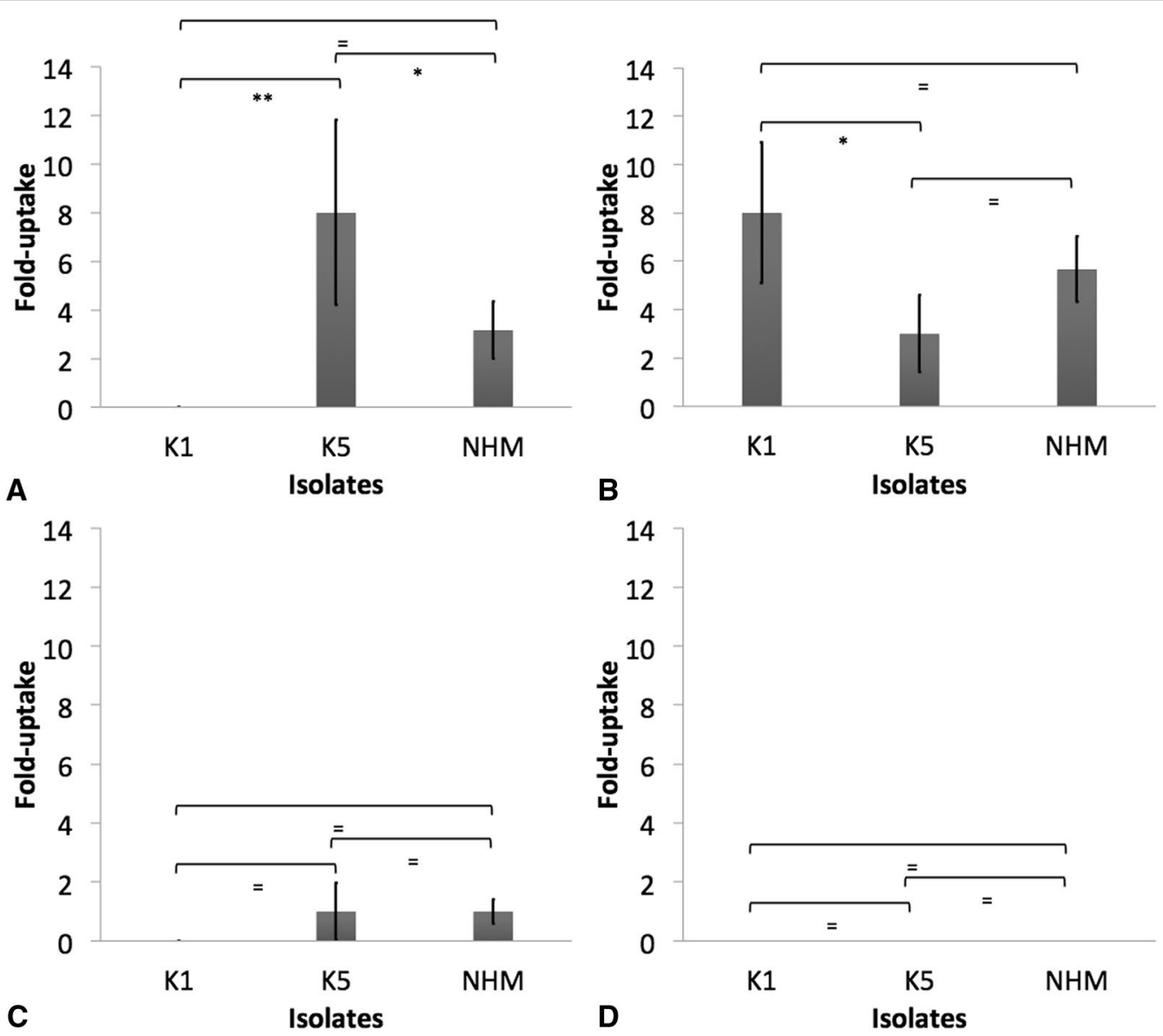

Figure 6 Peripheral blood mononuclear cells (PBMC) uptake of Klebsiella pneumoniae. Uptake of opsonized K1, K5, and non-HMV K. pneumoniae with normal serum $(\mathbf{A}$ and $\mathbf{B})$ or heat-inactivated serum $(\mathbf{C}$ and $\mathbf{D})$ from seropositive $(\mathbf{A}$ and $\mathbf{C})$ or seronegative $(\mathbf{B}$ and $\mathbf{D})$ donors by African Green monkey (AGM) PBMC was measured in vitro as described. The results are expressed as fold-uptake when compared to PBS opsonized bacteria. The error bars represent standard errors for triplicate samples, and the results shown are representative of three independent experiments. Asterisk indicates significant difference between treatments, $p \leq 0.05$; Double asterisk indicates significant difference between treatments, $p \leq 0.001$; Equal to indicates similarity between treatments, $p>0.05$.

complexes on the bacterial surface, while the alternative and lectin pathways are activated by cell surface components of bacteria. Activation of any of these three pathways leads to the opsonization of the target with the complement component C3b. Formation of C3b by a set of programmed enzymatic reactions proceeds to the assembly of a membrane attack complex (MAC) and bacteriolysis. It also plays a central role in the inflammatory process and modulates the activity of $\mathrm{T}$ - and B-cells. In addition, the complement receptors present on phagocytes bind $\mathrm{C} 3 \mathrm{~b}$ and $\mathrm{iC} 3 \mathrm{~b}$ molecules on the bacteria to induce phagocytosis [24, 32]. Similar binding of C3/C3b and $\mathrm{C} 5-9$ was detected in NHM, K1 and K5 isolates (Figure 3); however as already mentioned, greater susceptibility to complement-mediated killing was found in NHM strains. Serum-resistant K. pneumoniae have a reduced ability to bind $\mathrm{C1q}$, and this results in complement activation by serum-resistant strains principally via the alternative pathway; however serum-sensitive strains activate both the alternative and classical pathways, resulting in greater deposition of $\mathrm{C} 3 \mathrm{~b}$ and subsequent killing by the membrane attack complex [33, 34]. In this study, complement $\mathrm{C} 3 / \mathrm{C} 3 \mathrm{~b}$ binding to $K$. pneumoniae was significantly greater when serum from seropositive donors was used $(p<0.05)$, and although not significantly different, there was slightly greater binding of C5-9 in serum from seropositive donors (Figure 3). However, whole blood and serum killing assays indicate greater survival of $K$. pneumoniae in the presence of normal serum from seropositive donors when compared with normal serum from seronegative animals. Therefore a distinct correlation between complement deposition and 

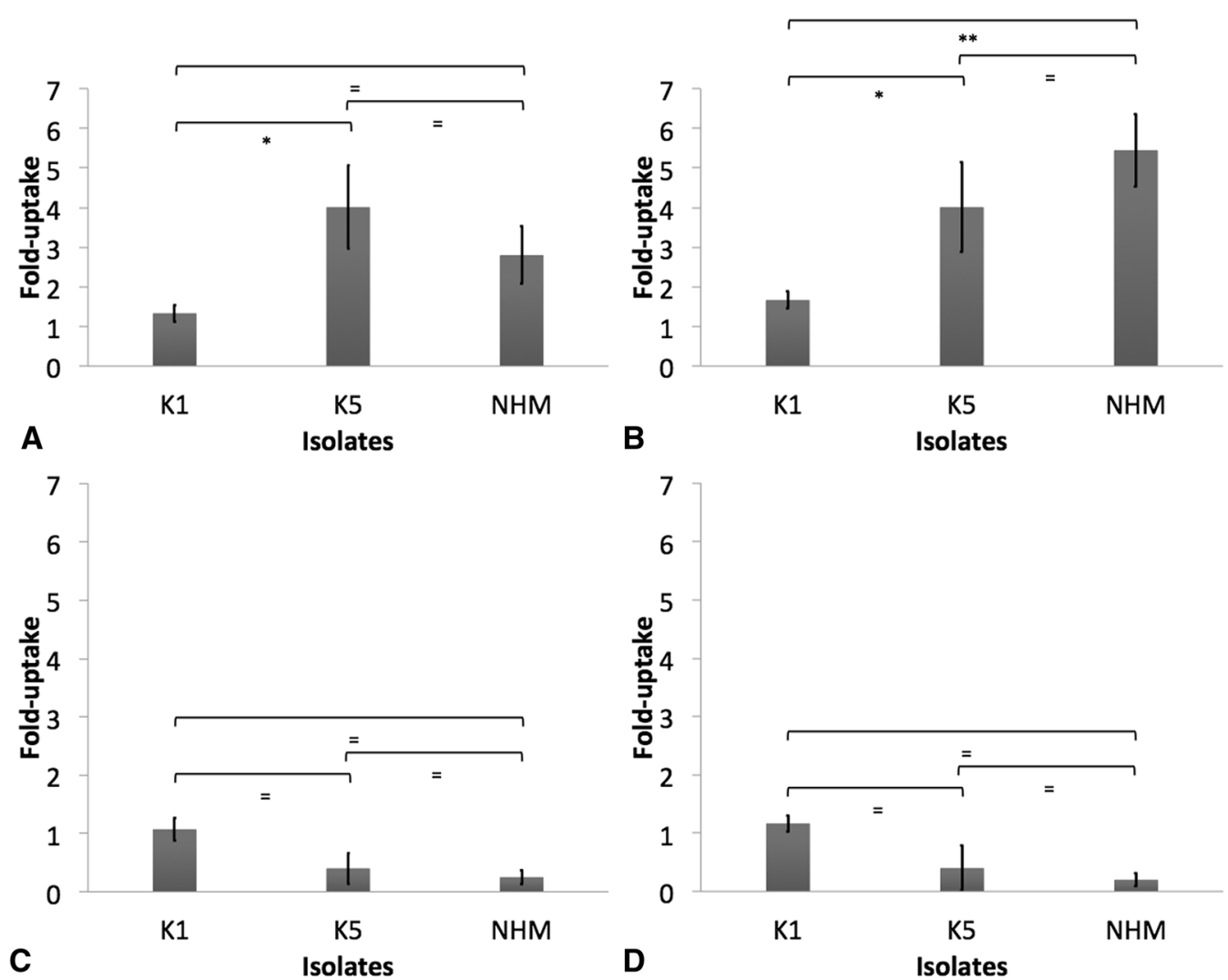

Figure 7 Polymorphonuclear leukocytes (PMNL) uptake of Klebsiella pneumoniae. Uptake of opsonized K1, K5, and non-HMV K. pneumoniae with normal serum (A and $\mathbf{B})$ or heat-inactivated serum $(\mathbf{C}$ and $\mathbf{D})$ from seropositive $(\mathbf{A}$ and $\mathbf{C})$ or seronegative (B and $\mathbf{D})$ donors by African Green monkey (AGM) PMNL was measured in vitro as described. The results are expressed as fold-uptake when compared to PBS opsonized bacteria. The error bars represent standard errors for triplicate samples, and the results shown are representative of three independent experiments. Asterisk indicates significant difference between treatments, $p \leq 0.05$; Double asterisk indicates significant difference between treatments, $p \leq 0.001$; Equal to indicates similarity between treatments, $p>0.05$

IgG titer supporting antibody-dependent complementmediated killing as the mechanism of bactericidal activity was not found (Figures 4 and 5 ). In contrast to our findings, Yeh et al. [35] reported that K1 and K2 HMV $K$. pneumoniae isolates recovered from liver abscess showed resistance to serum from normal human patients, but were significantly more susceptible to killing effects of serum when incubated with serum from patients with recurrent K1 K. pneumoniae liver abscesses. However, a direct comparison to Yeh et al. [35] findings is not possible since it is unknown if our serum donors had mounted an antibody response to K. pnemoniae from sub-clinical, clinical or recurrent infection. In some cases, bacteria can resist complement-mediated killing by immune serum, and this phenomenon has been reported in other members of the family Enterobactericeae like Salmonella enterica, and other Gram-negative and Gram-positive pathogens [21, 22, 36, 37].

The role of anti-Klebisella antibodies as opsonins was also explored using AGM PBMC and PMNL in in vitro uptake assays. In these experiments, there was greater uptake of bacteria by PMNL and macrophages when bacteria was opsonized with normal serum, indicating a role of complement in opsonization (Figure 8); however the greater amount of IgG on groups designated as "seropositive donors" did not appear to be protective, and as indicated by whole blood killing assays, incubation in heparinized blood from seronegative donors resulted in significantly less survival of HMV and non-HMV isolates $(p<0.05)$. Additionally, no oxidative burst activity was detected in PMNL and PBMC incubated with opsonized bacteria. Similar results have been reported in human PMNL stimulated with K. pneumoniae serotype K1, K2, K4 and K5 [11, 38] Further work by Sahly et al. [39] identified that the lower response of respiratory burst in human PMNL produced by some K. pneumoniae could be associated with lack of manno(rhamno) biose in the capsular polysaccharides of this bacteria. Thus, although complement increased opsonization of all $K$. pneumoniae (Figure 8); HMV isolates appear to 


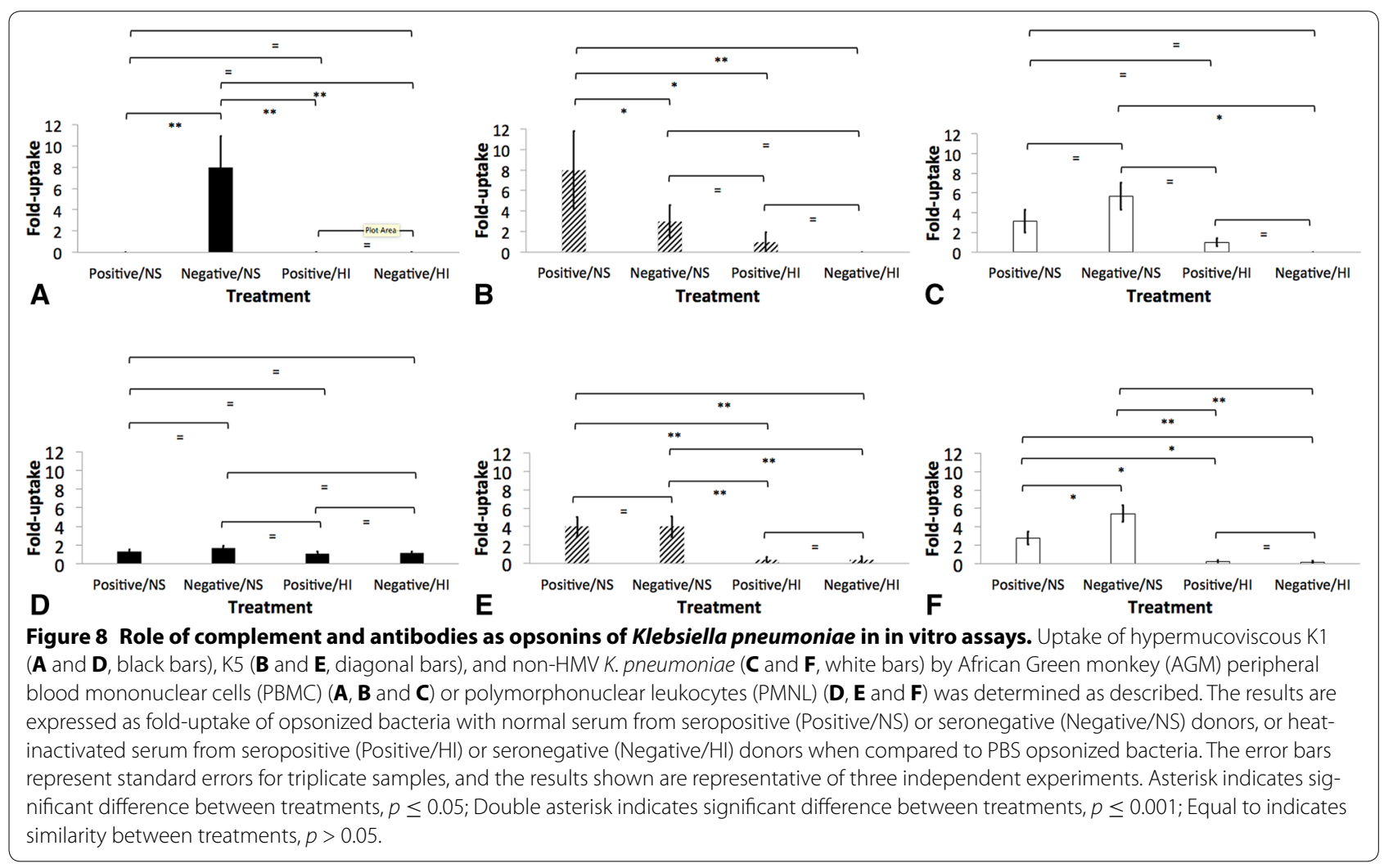

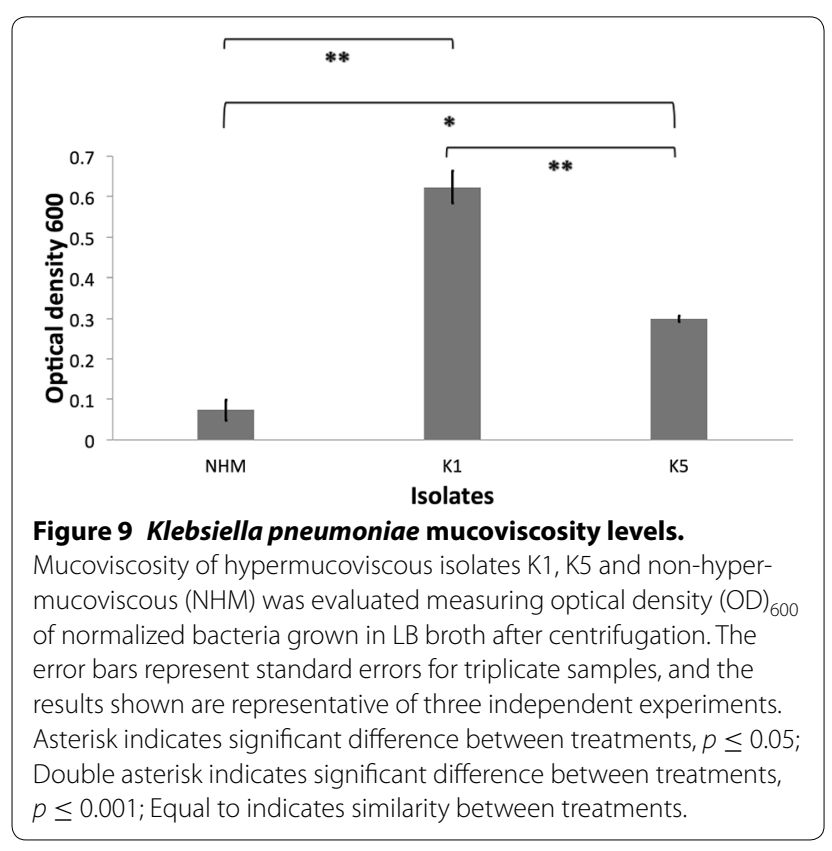

be resistant to killing even in presence of active complement and IgG and IgM. In S. enterica, there is a critical requirement for complement in opsonization and killing, as bacterium opsonization by antibodies alone results in negligible phagocytosis, oxidative burst and cellular killing by human peripheral blood cells [22]. In this study, significantly greater amounts of IgM were found binding to non-HMV isolates than to $\mathrm{K} 1$ and $\mathrm{K} 5$ isolates (Figure 1); thus IgM could be at least partially associated with greater protection at least against non-HMV isolates as indicated by greater susceptibility of non-HMV isolates in serum and whole blood killing. IgM has been shown to have more ability to activate complement on $S$. enterica than IgG [40]. The significantly greater amount of capsule present in HMV isolates $\mathrm{K} 1$ and $\mathrm{K} 5$ could be associated with complement mediated killing resistance in these isolates.

Immunoglobulin $\mathrm{G}$ is the most abundant immunoglobulin in primate serum. There are at least four different subclasses of IgG, and although they are highly conserved, they differ in their constant region, and have different effector functions [41]. It was interesting to find that seropositive donors had at least a partial deficiency in IgG2 (Figure 2). IgG2 deficiencies have been associated with increased susceptibility to certain bacterial infections [41]; and Alsaedi et al. [42] recently reported IgG2 deficiency and low IgM in a human patient presenting recurrent HMV $K$. pneumoniae bacteremia in the absence of pyogenic liver abscess or other localized metastatic Klebsiella infection. 
A major limitation in this study was the low number of seropositive and seronegative AGM donors. In the future, a better understanding on the recurrence of K. pneumoniae in non-human primates and other animals, and complete characterization of immunogens recognized by the host could be use to investigate the protective capacity of specific immunoglobulins to klebsiellosis. This can result in novel vaccines for humans and animals. In previous work, K1 K. pneumoniae isolates that were opsonized with serum from patients with recurrent $\mathrm{K} 1 \mathrm{~K}$. pneumoniae liver abscesses presented a significant increase in PMNL phagocytosis, compared to rates in K1 bacteria opsonized with serum from normal patients [35]; thus it appears that primates are able to mount protective immunity to $\mathrm{HMV}$ isolates. Wu et al. [43] reported that anti-capsular polysaccharide monoclonal antibodies agglutinate different strains of $K$. pneumoniae, including K1 serotype, enhanced phagocytosis by human monocyte-derived macrophages and protected mice in laboratory controlled in vivo challenges with magA + K. pneumoniae. Potential use of liveattenuated strains as vaccines has also been explored. Hsieh et al. [44] mutated O1:K1 and O1:K2 mutants deleting the $\mathrm{O} 1$ synthesizing genes and attenuated the strains as demonstrated in serum killing assays. Moreover, immunization of mice with a magA-mutant $\left(\mathrm{K}_{1}{ }^{-} \mathrm{O}_{1}\right)$ against LPS $\mathrm{O} 1$ provided protection against infection with an O1:K2 strain, but not against infection with an O1:K1 strain. [44] Cleary, more research investigating the host-pathogen interaction of hypervirulent and HMV strains with different in vivo and in vitro models are needed to better understand the pathogenesis of this emergent pathogen and to develop efficacious vaccines for humans and other animals.

Our findings highlight the complexity of the nonhuman primate immune response to HMV isolates of $K$. pneumoniae. These isolates evaded important components of the AGM innate and adaptive immune system, including serum- mediated killing, PBMC and PMNL phagocytosis and respiratory burst. Deeper understanding of the pathophysiology of infection with HMV $K$. pnemoniae related to virulence, resistance, and predisposing AGM host factors is required.

\begin{abstract}
Authors' contributions
ES conceived and designed the study. SM, AB, SF, KV and MV carried out sample collection, cells and serum purification and in vitro challenges, serological, microbiological and molecular work described in the experiment. MT carried out complete blood counts, blood chemistry, and serological analysis. MK carried out all statistical analysis on different experiments. ES, MV, RP and MT wrote the manuscript. All authors read and approved the final version of the manuscript.
\end{abstract}

\section{Author details}

1 Department of Epidemiology and Medicine, University of California, DavisSchool of Veterinary Medicine, Davis, CA, USA. ${ }^{2}$ Department of Biomedical
Sciences, Ross University School of Veterinary Medicine, Basseterre, St. Kitts, West Indies. ${ }^{3}$ Behavioural Science Foundation, Estridge Estate, Basseterre, St Kitts, West Indies. ${ }^{4}$ Department of Pathobiological Sciences, School of Veterinary Medicine, Louisiana State University, Baton Rouge, LA 70803, USA.

\section{Acknowledgements}

The authors thank Ross University School of Veterinary Medicine, and the Behavioural Science Foundation, for their generous financial support, as well the laboratory staff members of the two institutions for their technical help in collecting and processing of samples.

\section{Competing interests}

The authors declare that they have no competing interests.

Received: 22 September 2015 Accepted: 17 February 2016 Published online: 08 March 2016

\section{References}

1. Gozalo A, Montoyo E (1991) Klebsiella pneumoniae infection in a new world nonhuman primate center. Lab Primate Newsletter 30:13-20

2. Podschun R, Ullmann U (1998) Klebsiella spp. as nosocomial pathogens: epidemiology, taxonomy, typing methods, and pathogenicity factors. Clin Microbiol Rev 11:589-603

3. Lederman ER, Crum NF (2005) Klebsiella liver abscess: a coast-to-coast phenomenon. Clin Infect Dis 41:273

4. Doud MS, Grimes-Zeppegno R, Molina E, Miller N, Balachandar D, Schneper L, Poppiti R, Mathee K (2009) A k2A-positive Klebsiella pneumoniae causes liver and brain abscess in a Saint Kitt's man. Int J Med Sci 6:301-304

5. Jang S, Wheeler L, Carey RB, Jensen B, Crandall CM, Schrader KN, Jessup D, Colegrove K, Gulland FM (2010) Pleuritis and suppurative pneumonia associated with a hypermucoviscosity phenotype of Klebsiella pneumoniae in California sea lions (Zalophus californianus). Vet Microbiol 141:174-177

6. Soto E, LaMon V, Griffin M, Keirstead N, Beierschmitt A, Palmour R (2012) Phenotypic and genotypic characterization of Klebsiella pneumoniae isolates recovered from nonhuman primates. J Wildl Dis 48:603-611

7. Kawai T (2006) Hypermucoviscosity: an extremely sticky phenotype of Klebsiella pneumoniae associated with emerging destructive tissue abscess syndrome. Clin Infect Dis 42:1359-1361

8. Nadasy KA, Domiati-Saad R, Tribble MA (2007) Invasive Klebsiella pneumoniae syndrome in North America. Clin Infect Dis 45:e25-28

9. Lin YC, Lu MC, Tang HL, Liu HC, Chen CH, Liu KS, Lin C, Chiou CS, Chiang MK, Chen CM, Lai YC (2011) Assessment of hypermucoviscosity as a virulence factor for experimental Klebsiella pneumoniae infections: comparative virulence analysis with hypermucoviscosity-negative strain. BMC Microbiol 11:50

10. Shon AS, Bajwa RP, Russo TA (2013) Hypervirulent (hypermucoviscous) Klebsiella pneumoniae: a new and dangerous breed. Virulence 4:107-118

11. Simoons-Smit AM, Verweij-van Vught AM, Kanis IY, MacLaren DM (1985) Chemiluminescence of human leukocytes stimulated by clinical isolates of Klebsiella. J Med Microbiol 19:333-338

12. Fung CP, Chang FY, Lin JC, Ho DM, Chen CT, Chen JH, Yeh KM, Chen TL, Lin YT, Siu LK (2011) Immune response and pathophysiological features of Klebsiella pneumoniae liver abscesses in an animal model. Lab Invest 91:1029-1039

13. Roe WD, Rogers L, Pinpimai K, Dittmer K, Marshall J, Chilvers BL (2015) Septicaemia and meningitis caused by infection of New Zealand sea lion pups with a hypermucoviscous strain of Klebsiella pneumoniae. Vet Microbiol 176:301-308

14. Twenhafel NA, Whitehouse CA, Stevens EL, Hottel HE, Foster CD, Gamble S, Abbott S, Janda JM, Kreiselmeier N, Steele KE (2008) Multisystemic abscesses in African green monkeys (Chlorocebus aethiops) with invasive Klebsiella pneumoniae - identification of the hypermucoviscosity phenotype. Vet Pathol 45:226-231

15. Turton JF, Perry C, Elgohari S, Hampton CV (2010) PCR characterization and typing of Klebsiella pneumoniae using capsular type-specific, variable 
number tandem repeat and virulence gene targets. J Med Microbiol 59:541-547

16. Nassif X, Fournier JM, Arondel J, Sansonetti PJ (1989) Mucoid phenotype of Klebsiella pneumoniae is a plasmid-encoded virulence factor. Infect Immun 57:546-552

17. Cox BL, Schiffer H, Dagget G Jr, Beierschmitt A, Sithole F, Lee E, Revan F, Halliday-Simmonds I, Beeler-Marfisi J, Palmour R, Soto E (2015) Resistance of Klebsiella pneumoniae to the innate immune system of African green monkeys. Vet Microbiol 176:134-142

18. Hartman LJ, Selby EB, Whitehouse CA, Coyne SR, Jaissle JG, Twenhafel NA, Burke RL, Kulesh DA (2009) Rapid real-time PCR assays for detection of Klebsiella pneumoniae with the rmpA or magA genes associated with the hypermucoviscosity phenotype: screening of nonhuman primates. J Mol Diagn 11:464-471

19. Fang CT, Chuang YP, Shun CT, Chang SC, Wang JT (2004) A novel virulence gene in Klebsiella pneumoniae strains causing primary liver abscess and septic metastatic complications. J Exp Med 199:697-705

20. Hsu CR, Lin TL, Chen YC, Chou HC, Wang JT (2011) The role of Klebsiella pneumonia rmpA in capsular polysaccharide synthesis and virulence revisited. Microbiology 157:3446-3457

21. MacLennan CA, Gondwe EN, Msefula CL, Kingsley RA, Thomson NR, White SA, Goodall M, Pickard DJ, Graham SM, Dougan G, Hart CA, Molyneux ME, Drayson MT (2008) The neglected role of antibody in protection against bacteremia caused by nontyphoidal strains of Salmonella in African children. J Clin Invest 118:1553-1562

22. Gondwe EN, Molyneux ME, Goodall M, Graham SM, Mastroeni P, Drayson MT, MacLennan CA (2010) Importance of antibody and complement for oxidative burst and killing of invasive nontyphoidal Salmonella by blood cells in Africans. Proc Natl Acad Sci U S A 107:3070-3075

23. Lin JC, Chang FY, Fung CP, Xu JZ, Cheng HP, Wang JJ, Huang LY, Siu LK (2004) High prevalence of phagocytic-resistant capsular serotypes of Klebsiella pneumoniae in liver abscess. Microbes Infect 6:1191-1198

24. Wooster DG, Maruvada R, Blom AM, Prasadarao NV (2006) Logarithmic phase Escherichia coli K1 efficiently avoids serum killing by promoting C4bp-mediated C3b and C4b degradation. Immunology 117:482-493

25. Miller VL (2014) Klebsiella: a long way to go towards understanding this enigmatic jet-setter. F1000Prime Rep 6:64

26. Simoons-Smit AM, Verweij-van Vught AM, MacLaren DM (1986) The role of $\mathrm{K}$ antigens as virulence factors in Klebsiella. J Med Microbiol 21:133-137

27. Yeager JJ, Facemire P, Dabisch PA, Robinson CG, Nyakiti D, Beck K, Baker R, Pitt ML (2012) Natural history of inhalation melioidosis in rhesus macaques (Macaca mulatta) and African green monkeys (Chlorocebus aethiops). Infect Immun 80:3332-3340

28. Jasinska AJ, Schmitt CA, Service SK, Cantor RM, Dewar K, Jentsch JD, Kaplan JR, Turner TR, Warren WC, Weinstock GM, Freimer NB, Woods RP (2013) Systems biology of the vervet monkey. ILAR J 54:122-143

29. Alvarez D, Merino S, Tomás JM, Benedí VJ, Albertí S (2000) Capsular polysaccharide is a major complement resistance factor in lipopolysaccharide O side chain-deficient Klebsiella pneumoniae clinical isolates. Infect Immun 68:953-955
30. Tomás JM, Benedí VJ, Ciurana B, Jofre J (1986) Role of capsule and O antigen in resistance of Klebsiella pneumoniae to serum bactericidal activity. Infect Immun 54:85-89

31. Merino S, Camprubí S, Albertí S, Benedí VJ, Tomás JM (1992) Mechanisms of Klebsiella pneumoniae resistance to complement-mediated killing. Infect Immun 60:2529-2535

32. Merle NS, Noe R, Halbwachs-Mecarelli L, Fremeaux-Bacchi V, Roumenina LT (2015) Complement system part II: role in immunity. Front Immunol 6:257

33. Albertí S, Marqués G, Hernández-Allés S, Rubires X, Tomás JM, Vivanco F, Benedí VJ (1996) Interaction between complement subcomponent C1q and the Klebsiella pneumoniae porin OmpK36. Infect Immun 64:4719-4725

34. Albertí S, Alvarez D, Merino S, Casado MT, Vivanco F, Tomás JM, Benedí VJ (1996) Analysis of complement C3 deposition and degradation on Klebsiella pneumoniae. Infect Immun 64:4726-4732

35. Yeh FC, Yeh KM, Siu LK, Fung CP, Yang YS, Lin JC, Chang FY (2012) Increasing opsonizing and killing effect of serum from patients with recurrent K1 Klebsiella pneumoniae liver abscess. J Microbiol Immunol Infect 45:141-146

36. McIntosh ED, Bröker M, Wassil J, Welsch JA, Borrow R (2015) Serum bactericidal antibody assays - The role of complement in infection and immunity. Vaccine 33:4414-4421

37. Mulye M, Bechill MP, Grose W, Ferreira VP, Lafontaine ER, Wooten RM (2014) Delineating the importance of serum opsonins and the bacterial capsule in affecting the uptake and killing of Burkholderia pseudomallei by murine neutrophils and macrophages. PLoS Negl Trop Dis 8:e2988

38. Podschun R, Penner I, Ullmann U (1992) Interaction of Klebsiella capsule type 7 with human polymorphonuclear leucocytes. Microb Pathog 13:371-379

39. Sahly H, Keisari Y, Ofek I (2009) Manno(rhamno) biose-containing capsular polysaccharides of Klebsiella pneumoniae enhance opsono-stimulation of human polymorphonuclear leukocytes. J Innate Immun 1:136-144

40. Robbins JB, Kenny K, Suter E (1965) The isolation and biological activities of rabbit $\gamma \mathrm{M}$ and $\gamma$ G-anti-Salmonella typhimurium antibodies. J Exp Med 122:385-402

41. Vidarsson G, Dekkers G, Rispens T (2014) IgG subclasses and allotypes: from structure to effector functions. Front Immunol 5:520

42. Alsaedi A, Janower A, Wang JT, Nichol K, Karlowsky J, Orr P, Keynan Y (2014) Hypermucoviscous Klebsiella syndrome without liver abscess in a patient with immunoglobulin g2 immune deficiency. Open Forum Infect Dis 1:ofu080

43. Wu MF, Yang CY, Lin TL, Wang JT, Yang FL, Wu SH, Hu BS, Chou TY, Tsai MD, Lin CH, Hsieh SL (2009) Humoral immunity against capsule polysaccharide protects the host from magA + Klebsiella pneumoniae-induced lethal disease by evading Toll-like receptor 4 signaling. Infect Immun 77:615-621

44. Hsieh PF, Lin TL, Yang FL, Wu MC, Pan YJ, Wu SH, Wang JT (2012) Lipopolysaccharide $\mathrm{O} 1$ antigen contributes to the virulence in Klebsiella pneumoniae causing pyogenic liver abscess. PLoS One 7:e33155

\section{Submit your next manuscript to BioMed Central and we will help you at every step:}

- We accept pre-submission inquiries

- Our selector tool helps you to find the most relevant journal

- We provide round the clock customer support

- Convenient online submission

- Thorough peer review

- Inclusion in PubMed and all major indexing services

- Maximum visibility for your research

Submit your manuscript at www.biomedcentral.com/submit

C Biomed Central 